\title{
Commercial vegetable farming: an approach for poverty reduction in Nepal1
}

\author{
Bhimsen Gurung, RB Thapa, DM Gautam, KB Karki and PP Regmi \\ Institute of Agriculture and Animal science' Rampur, Chitwan \\ Email: bhimseng@yahoo.com
}

\section{Abstract}

Poverty reduction of farmers from Kapilbastu and Kaski districts were evaluated with respect to the vegetable farming where PRISM (Prosperity Realization through Irrigation and Smallholder Markets) technology was implemented. After the implementation of PRISM there has been considerable increase in vegetable farming area in both districts. Numbers of vegetable crops grown were increased with respect to yield and net return from both the winter and summer vegetables. With the opening of organized markets and large scale increase in income, farmers were attracted towards vegetable cultivation that provided wide range of vegetables for consumers as well. Earlier farmers cultivated vegetables only when there would be fallow land after the harvest of main season cereal crops while after the adoption of new technology farmers grew vegetables all the year round. Among the popular vegetables during summer was cucumber in the hills and okra in the Terai covering more land than other vegetables crops in the study area. These crops help farmers achieve net return of NRs.25240.6 and from NRs. 20425.4 per Ropani in Kaski and Kapilbastu, respectively. Land area under vegetables crops were increased by 6 times in Kaski and 12 times in Kapilbastu. This increase in net return has been found as a result of creating better marketing system developed by the activity of the PRISM. Similarly, involvement of household in summer season vegetable was not enough and farmers hired labor for commercial vegetables cultivation.

Keywords: PRISM approach, vegetable subsector, subsistence farming, commercialization, marketing channel

\section{Introduction}

Vegetables are considered very important crops both from the point food and economic value in providing cheap source of nutrients and vitamins. At the same time, they are also considered high value cash crops as they provide almost 5 to 10 times higher economic value (Pun and Karmacharya; 1998). With the expansion of urbanization and health consciousness of the people and awareness created by different media the demand of vegetables has increased over the years and hence increased in area, production and productivity. The area and production under vegetable is increased from merely 161048

\footnotetext{
${ }^{1}$ Part of the article submitted for the degree of the Doctor of Philosophy by the first author from the IAAS, Rampur, Tribhuvan University, Nepal
} 
hectares in 2001/02 to 244102ha in 2010/11 and production $1738086 \mathrm{mt}$ to $3203563 \mathrm{mt}$ respectively (CBS, 2011).

Majority of the Nepali Farmers have small holdings and have to specialize in production with a high return from a small area. In this regards commercial vegetables farming plays a major role. Vegetable crops are efficient to generate cash even from a small plot of land in a short period of time and helps farmers reduce poverty. The value of vegetable production equals or even surpasses the value of cereal production. Many of the smallholding farmers live under difficult conditions like in dry areas with no low water control technologies, viable supply chain for these technologies and far away from markets and services. Under such conditions, it is very difficult for them to produce high value crops like vegetables in the quality demanded and get higher prices. Hence, International Development Enterprises came up with PRISM approach to enable smallholders in vegetable subsector and get out of poverty by generating income from high value crops including seasonal and off season vegetable production in the study area.

\section{Intensive vegetables farming approach}

A project namely Prosperity Realization through Irrigation and Smallholder Market (PRISM) was implemented in these two districts through International Development Enterprises (IDE).This project ran for 10 years from 2003 to 2011. The approach taken to implement the program was a sustainable opportunities through market-oriented interventions of creating networks of small enterprises to provide agricultural supplies needed by the poor farmers; working with farmers to improve small-farm productivity; and linking small-farm families to markets for effective and sustainable poverty reduction. 


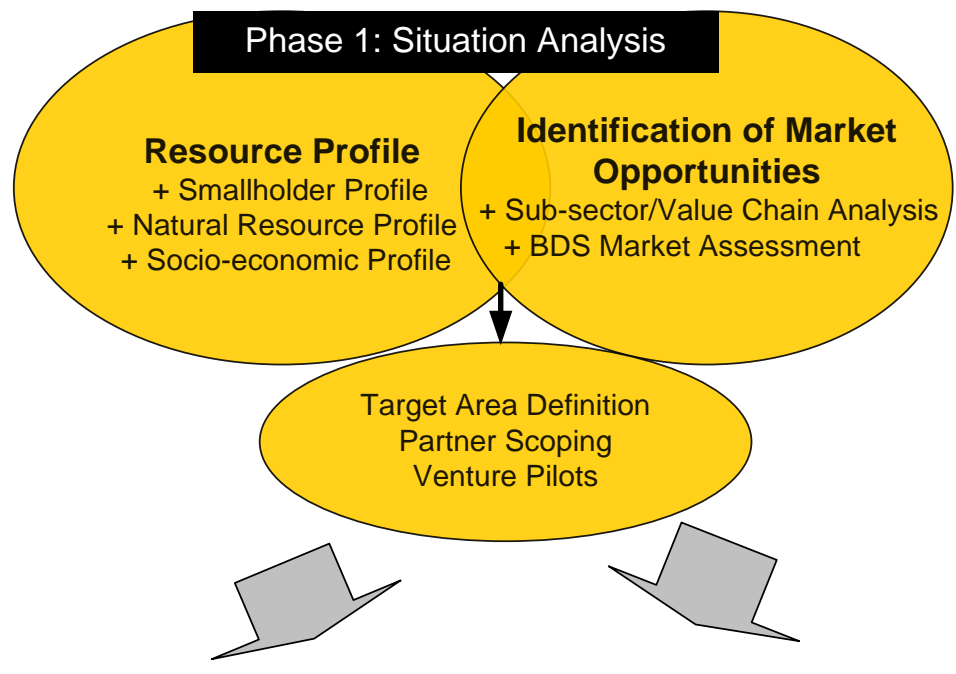

Phase 2: Intervention Design

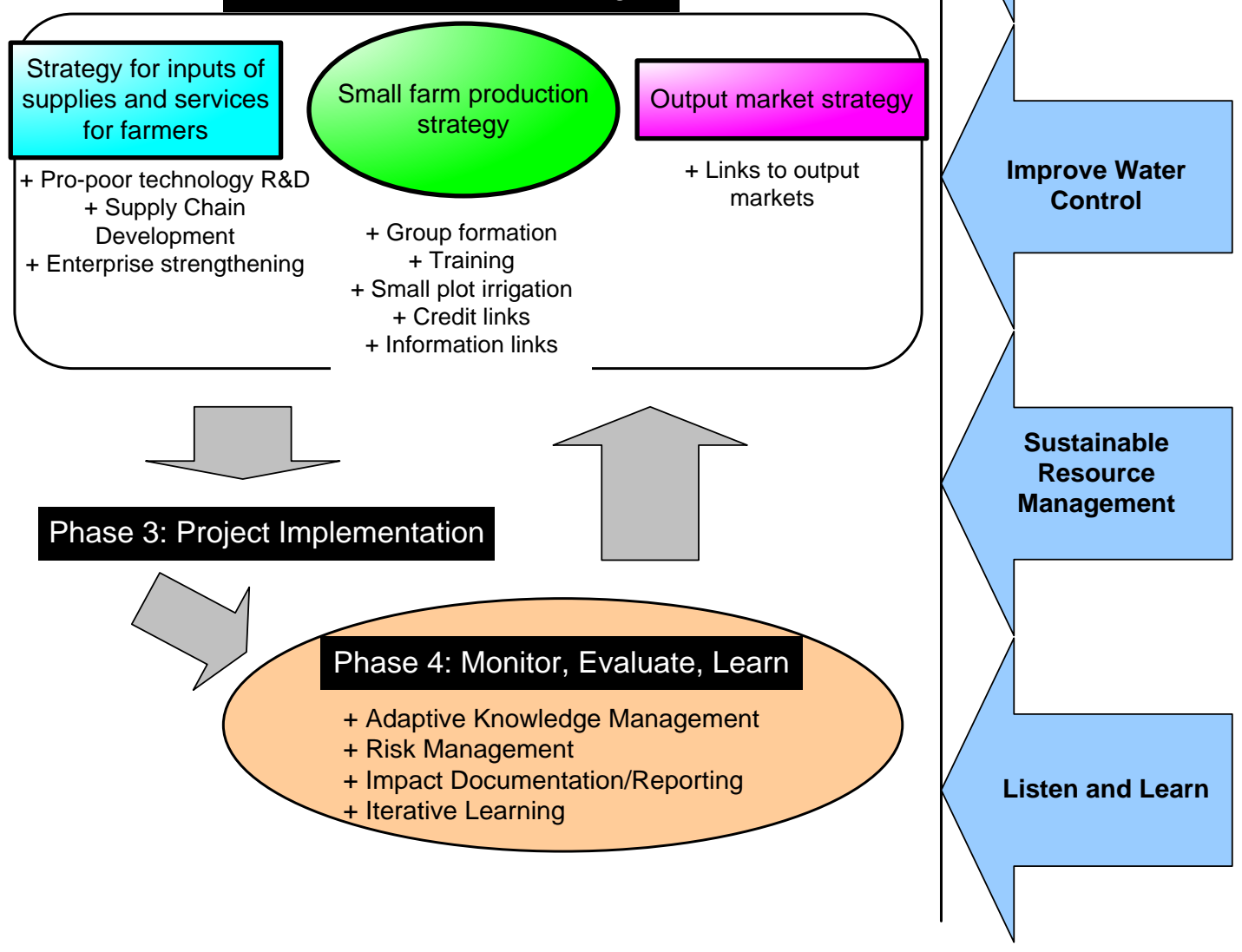

Fig 1. Technology transfer and farming process applied in the study area (Adopted from IDE,2007) 


\section{Methodology}

Intensive cultivated areas of two districts were Kaski in the hill and Kapilabastu in the Terai selected for the study. Data were collected through, focus group discussion, consultative meetings, participatory appraisal meetings, household survey and meetings with the project staff, government staff and different secondary documents. Questionnaires and checklists were prepared for the collection of information which was pre-tested in the real field situation. The improvement and finalization of the questionnaires were done after the pre- tested. Twenty five participatory rural appraisal meetings (10 from Kaski and 15 from Kapilbastu) were held in the project sites. In all the places, intensive vegetable growers were gathered and discussed. The house hold survey was done in 15 different groups covering 105 household heads in Kaski and 24 groups in Kapilbastu covering 168 farm household. All survey household were selected randomly by using random table number. Data collected were analyzed using SPSS 15.0 statistical program and interpreted accordingly and presented in different forms of graphs. The data where statistical analysis was not possible logical interpretation was applied. The data of farmers' condition before the project and after is compared to see the impact of technology and organized marketing for agricultural development and poverty alleviation.

\section{Result and discussion}

Survey results showed that average area under vegetable farming in both the district was found increased (Table 1). The average area under vegetable cultivation in Kaski and Kapilbastu increased from 0.07 and 0.11 ha after the project. The same increasing trend was found in the case of total persons working in vegetable farms. Both the male and female member working in vegetable farm was also increased after ten years' participating in the program indicating increased inclination of farmers towards commercial vegetable farming. The number of hired female labor was more in Kaski as compared to Kapilbastu. The number of female labor was more as compared to the male labor in Kaski. The male labor received $28 \%$ more wages than that of the female counterpart. Nearly $47 \%$ and 42 $\%$ of more wages was received by male labor in Kaski district than that of the female labor before and after the PRISM project, respectively. Similarly, $31 \%$ and $16 \%$ more wages was received by male labor in Kapilbastu before and after the PRISM, respectively. Nepalese farmers needed technology that helps them to boost agricultural production. Research, development and extension activity should go side by side for to yield increased crop productivity. Technology has a definite mechanisms which needs to be followed systematically (Sunding and Zilberman, 2001). The small famers do not have access to technology as they do not want to take the risk to increase their production. Similar is the case of African small farmers (Zeller et al; 1998). The PRISM project bought the technology which was constantly monitored the farmers from the beginning to the end of the product disposal. Farmers need institutional support for the adaptation of agricultural 
technology to boost agricultural production (Byerlee, 1994). This increased in the area is due to consumers', demand and organized market available for farmers to sell their farm products (Fafchamps, 1992; Susanne and Carolyn, 2005). Since this vegetables farming generated cash income of the farmers in short period for which farmers could use money obtained from the vegetable farming for utilization of succeeding input purchase as the small scale vegetable cultivation did not need large sum of money (Dutt, 2014; Rana, 1990). This could also be true that the adoption of technology depends on the types of technology and the adoption (Adesina and Baidu-Forson, 1995).

Table 1. Labor situation in the project areas

\begin{tabular}{|c|c|c|c|c|c|c|c|c|c|}
\hline \multirow[b]{2}{*}{ Particulars } & \multicolumn{3}{|l|}{ Kaski } & \multicolumn{3}{|c|}{ Kapilbastu } & \multicolumn{3}{|l|}{ Both } \\
\hline & Before & After & $\begin{array}{l}\% \\
\text { change }\end{array}$ & Before & $\begin{array}{l}\text { Afte } \\
\mathbf{r}\end{array}$ & $\begin{array}{l}\% \\
\text { chan } \\
\text { ge }\end{array}$ & $\begin{array}{l}\text { Befo } \\
\text { re }\end{array}$ & After & $\begin{array}{l}\% \\
\text { chan } \\
\text { ge }\end{array}$ \\
\hline Total cultivated area & $\mathrm{n} / \mathrm{a}$ & 0.45 & $\mathrm{n} / \mathrm{a}$ & $\mathrm{n} / \mathrm{a}$ & 0.46 & $\mathrm{n} / \mathrm{a}$ & $\mathrm{n} / \mathrm{a}$ & 0.46 & $\mathrm{n} / \mathrm{a}$ \\
\hline $\begin{array}{l}\text { 1.Your total land area under } \\
\text { vegetable cultivation in } \mathrm{Ha}\end{array}$ & 0.03 & 0.07 & 233 & 0.09 & 0.11 & 122 & 0.03 & 0.1 & 333 \\
\hline $\begin{array}{l}2, \text { Total person working in your } \\
\text { vegetable farm }\end{array}$ & 2 & 3 & 150 & 2 & 3 & 150 & 2 & 3 & 150 \\
\hline $\begin{array}{l}\text { 3. Family Male member } \\
\text { working in your farm }\end{array}$ & 1 & 1.2 & 120 & 1.6 & 1.7 & 106 & 1 & 1.5 & 150 \\
\hline $\begin{array}{l}\text { 4.Family Female member } \\
\text { working in your farm }\end{array}$ & 1 & 1,3 & 130 & 1.3 & 1.8 & 138 & 1.2 & 1.6 & 133 \\
\hline $\begin{array}{l}\text { 5.Hired male labor working in } \\
\text { your farm }\end{array}$ & 1 & 1.3 & 130 & 1.3 & 2.3 & 177 & 1.2 & 1.8 & 150 \\
\hline $\begin{array}{l}\text { 6.Hired female labor working } \\
\text { in your farm }\end{array}$ & 26 & 21 & (19) & 1.5 & 1.7 & 113 & 9 & 12 & 133 \\
\hline 7.Wage of male labor Rs./day & 198 & 394 & 198 & 96 & 208 & 217 & 128 & 264 & 206 \\
\hline $\begin{array}{l}\text { 8. Wage of female labor } \\
\text { Rs./day }\end{array}$ & 105 & 227 & 216 & 66 & 175 & 265 & 78 & 190 & 244 \\
\hline
\end{tabular}

\section{Area, production and net return of different vegetables}

The area under major summer vegetables is increased by almost double as compare to ten years earlier in both the district. Area covered by different vegetables fluctuated based on the market prices of the commodities so was the net profit obtained from the vegetables cultivation (Table 2). There has been a large difference in the yield of major vegetables as a result the net profit has been increased. In both the district winter crops paid higher return than the summer crops. In the hills the net profit after the project was 4.6 times (NRs. 17821.72 after Project) higher than earlier of the project in case of summer vegetables where as the winter vegetables gave higher of 8.4 times (NRs. 31007.34). Net return in the Terai was not that much and was only 1.1 times in summer vegetables whereas the winter vegetables different was only 1.1 times (Table 2). This increase in net return in the hill may be due to increase in the area in the hills for both winter and summer vegetables crops. The increase in the hill could be due to increase in the land area under cultivation which was s promoted by the organized marketing system (Pokherel, 2010). 
There has been controversy in the adaptation of new technology which depended on the land holdings because of the risk in the adaptation of by small farmers when the marketing is assured even the small farmers can take the risk of adaptation (Zeller et al; 1998).

Table 2. Comparison of area, production and, net return from two season vegetable crops in the study area

\begin{tabular}{|c|c|c|c|c|c|c|c|c|c|c|c|c|c|}
\hline \multirow[t]{2}{*}{ SN } & \multirow[t]{2}{*}{$\begin{array}{c}\text { Name of } \\
\text { Vegetable } \\
\text { s }\end{array}$} & \multicolumn{2}{|c|}{$\begin{array}{c}\text { Area } \\
\text { (Sq.meter) }\end{array}$} & \multicolumn{2}{|c|}{$\begin{array}{c}\text { Total } \\
\text { production }(\mathbf{k g})\end{array}$} & \multicolumn{2}{|c|}{$\begin{array}{c}\text { Cost of } \\
\text { Production } \\
\text { (NRs) }\end{array}$} & \multicolumn{2}{|c|}{$\begin{array}{l}\text { Price/r Kg } \\
\text { (NRs) }\end{array}$} & \multicolumn{2}{|c|}{$\begin{array}{l}\text { Total Return } \\
\text { (NRs) }\end{array}$} & \multicolumn{2}{|c|}{$\begin{array}{l}\text { Net Return } \\
\text { (NRs) }\end{array}$} \\
\hline & & $\begin{array}{l}\text { Bef } \\
\text { ore }\end{array}$ & After & Before & After & Before & After & Before & After & $\begin{array}{l}\text { Befo } \\
\text { re }\end{array}$ & & $\begin{array}{l}\text { Bef } \\
\text { ore }\end{array}$ & $\begin{array}{l}\text { Afte } \\
\mathbf{r}\end{array}$ \\
\hline \multirow[t]{4}{*}{ Hill } & (Summer & 416. & 793. & 523.6 & 152 & 1540.79 & 2526 & 50.2 & 75. & 5398 & 203 & 379 & 1782 \\
\hline & veg.) & 89 & 03 & 6 & 37 & & .02 & & 3 & & 83 & 8.8 & 1.72 \\
\hline & Winter & 349. & 612. & 376.8 & 1348. & 1129.07 & 3115 & 81.7 & 131. & 4831 & 34124. & 367 & 3100 \\
\hline & Veg. & 9 & 3 & 9 & 8 & & .38 & 4 & 57 & .3 & 01 & 1.3 & 7.34 \\
\hline \multirow[t]{4}{*}{ Terai } & (Summe & 116 & 1356 & 1550 & 1867. & 4300 & 6276 & 155 & 76.4 & 2175 & 26860. & 174 & 2003 \\
\hline & veg.) & 5 & .65 & & 67 & & .29 & & 5 & 0 & 28 & 50 & 0 \\
\hline & Winter & 776. & 1819 & 2033. & 3089. & 4000 & 9609 & 49 & 85.0 & 3600 & 41961. & 320 & 3253 \\
\hline & Veg. & 33 & .85 & 3 & 02 & & & & 1 & 0 & 83 & 00 & 7.99 \\
\hline
\end{tabular}

For crop intensification growing of more crops using modern technology is necessary to meet the food and nutrition demand of consumers and hence food security. This increase is credited to the modern inputs that farmers use and irrigation is the important one which was used substantially and sustainably. Koundouri et al (2006) also emphasized the use of sustainable water for crop production. Small farmers generally do not accept the new technology because of risk of failure. When the adopted technology fails the farmers are doomed but they can accept the technology when all from production to the supply of inputs as well product is assured. Opara, (2003) observed the same situation in African farms. To met the consumers' demand and boost agriculture production environment quality and sustainability cannot be compromised (Tilman et al; 2002; Zwick et al; 2008).

\section{Production, consumption and net return of vegetable in the sample area}

There has been a tremendous increase in production of vegetables in surveyed area over the period of ten years. About 6 times increase in vegetable production in Kaski and 12 times increase in vegetable production in Kapilbastu had been observed. The productivity of vegetables per ha has also increased from $24 \mathrm{mt}$ to $28.8 \mathrm{mt}$ in Kaski and $4.2 \mathrm{mt}$ to 17.8 $\mathrm{mt}$ in Kapilbastu. Together the increase in productivity was from 10.28 to $22.2 \mathrm{MT}$ per ha. Before ten years, on an average about $48 \%$ of vegetable produced is consumed while only $22 \%$ of vegetable produced is consumed after ten years indicating that about $78 \%$ of vegetable produced is sold in the market. The consumption of vegetables is found more in Kaski as compared to Kapilbastu. Over the period, the net income increased per household from the sale of vegetable is from Nrs.1166.69 to Nrs.25240.6 and from NRs. 4451.75 to NRs. 20425.4 in Kaski and Kapilbastu respectively. On an average, the net increase in 
household income of the surveyed area from the sale of vegetable is from NRs. 1635.98 to NRs.22451.8. (Table 3).

Food consumption by the family before and after the project has decreased in the percentage basis. The total amount of vegetables consumed by the farmers' family must have been increased. It is because of the total volume of the vegetables produced is higher earlier to project and later. Earlier the farmers consumed only $250 \mathrm{~kg}$ at $52 \%$ of the production whereas $22.3 \%$ of $2726 \mathrm{~kg}$ comes to be $607.89 \mathrm{~kg}$ in a year indication $1.7 \mathrm{~kg}$ of vegetables in a day. This amount of vegetables substantially substitute nutrient requirement of the family and food security (Knai et al; 2006; Maxwell and Slater, 2003). This is because of the availability of vegetables in the farm (Rasmussen et al; 2006).

Table 3. Production, consumption and net return of vegetable grown in the sample area

\begin{tabular}{|c|c|c|c|c|c|c|}
\hline \multirow{2}{*}{ Particulars } & \multicolumn{2}{|l|}{ Kaski } & \multicolumn{2}{|c|}{ Kapilbastu } & \multicolumn{2}{|l|}{ Both } \\
\hline & Before & After & Before & After & Before & After \\
\hline Production in Metric ton & 481.19 & 2726 & 200.5 & 2569.4 & 681.7 & 5295.5 \\
\hline Production Kg/Ropani & 1243 & 1443 & 213 & 892 & 514 & 1110.4 \\
\hline Production $\mathrm{mt} / \mathrm{Ha}$ & 24 & 28.8 & 4.2 & 17.8 & 10.28 & 22.2 \\
\hline Home consumption in $\%$ & 52 & 23.3 & 32 & 22 & 48 & 22 \\
\hline Sell \% & 48 & 76.7 & 68 & 78 & 52 & 78 \\
\hline \multicolumn{7}{|l|}{ Approximate gross income/HH } \\
\hline Minimum in NRs & 520 & 9840.4 & 20966 & 12080 & 8384.61 & 11193.8 \\
\hline Maximum in NRs & 11520 & 44318 & 26000 & 39787 & 16950 & 41606 \\
\hline Approximate net income $/ \mathrm{HH}$ & 1166.69 & 25240.6 & 4451.75 & 20425.4 & 1635.98 & 22451.8 \\
\hline
\end{tabular}

Vegetables consumption in the developed country is regarded as low nutrient density (LND) food. Lack of LND in the food table developed obesity among the American children and adolescent (Kant, 2003). Although meat and milk products are high in nutrients, vitamins and protein poor and marginal farmers cannot afford to serve these items because of high price. The people in the developing countries are over nutrients because of their purchasing power and can afford these high nutrients food. As a consequences there has been increase in the chronic diseases in the developed countries including USA (Welch and Graham, 1999) and hence vegetables is regarded as LND and the US food policy recommends vegetables and fruits to include these LND as a part of the everyday diet (Bazzano et al; 2003; Krebs-Smith et al; 2010). Whereas our Nepalese subsistence farmers consumes sufficient vegetable in their everyday diet that decreases the risk of cardiovascular diseases (Lampe, 1999). In addition to supply of vitamins, trace minerals and dietary fibers and other biologically active compounds that helps fight the chronic diseases (Moser et al; 1988).

\section{Percentage of sample household growing vegetable in different months of the year}


Nepal has the advantages of climatic condition. We can grow different winter and summer vegetables simultaneously taking advantages of altitude. In the three different physiographic regions, potato can be harvested all the year round. During winter potato comes up well in the Terai whereas during that period mountains are full of snow but it will be too hot for potato to grow during summer in the Terai. At this season in the hills and mountain potato thrives well and gives good production (Pun and Karmacharya, 1998)

There has been a significant increase in the percentage of sample households growing vegetables over the period of ten years. This figure in the case of Kaski has increased as high as $55 \%$ against no one growing in March to $96 \%$ against $16.5 \%$ during the month of October (Fig.1). In the case of Kapilbastu less than $1 \%$ of sample households was growing vegetables earlier while up to $85 \%$ of the samples households have been growing vegetables after the project period. The percentage of household growing vegetable during the month of June to August in Kaski ( Fig.1) is comparatively low before and after the period of ten years. (Fig.2). This is due to the fact that Pokhara area is the highest rainfall area of Nepal as $80 \%$ of the rain falls during these months (Kansakar et al; 2004). Figure3 shows the percentage of household growing vegetables throughout the year within the period of ten years both in Kaski and Kapilbastu. The figure reveals that the percentage of sample household growing vegetable was $0 \%$ to less than $13 \%$ in January before ten years. Around $12 \%$ of growers in August and $89 \%$ growers in November have been observed after the period of ten years. The precipitation pattern indicates that as west we go precipitation pattern decreases. In addition to summer precipitation winter precipitation in the mid and far-western is higher because of wind carrying precipitation from Arabian Sea breeze. Western mountains receive heavy summer precipitation concentrating in June to August during which $>80 \%$ rain falls (Ichiyanagi et al; 2007).

The farmers know that heavy precipitation creates poor drainage and vegetable cannot thrive well. In addition, there will be heavy attack of pests and diseases as the humidity and temperature is favorable for the fungal and bacterial diseases for which soil management is difficult (Abawi and Widmer, 2000). Even after harvest of the crops transportation sometimes is disturbed and when they remain in the field or in the storage development of aflatoxin develops because of temperature and humidity (Ichiyanagi et al; 2007). As a result production of vegetables crops during June to August is restricted and green production controlling humidity and temperature is possible (Jetiyanon et al; 2003; Louren; 2008). Because of weak structure of Nepalese landscape frequent landslides occur in the Nepalese mountains and Siwaliks which disturbs road transportation(Tamrakar et al; 2002). 


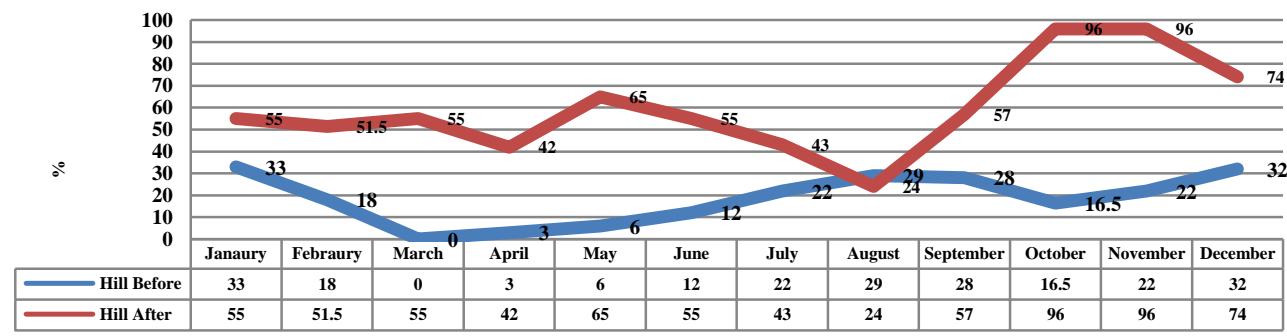

Figure 2. Vegetable Grown in hill district, Kaski

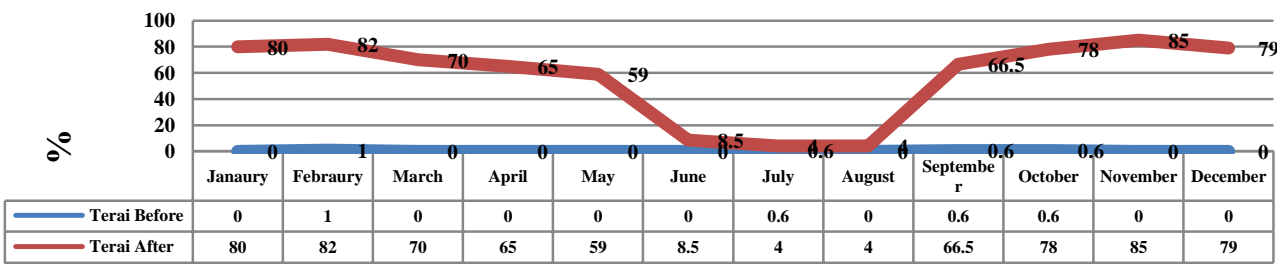

Figure 3. Vegetable grown in Terai district, Kapilbastu

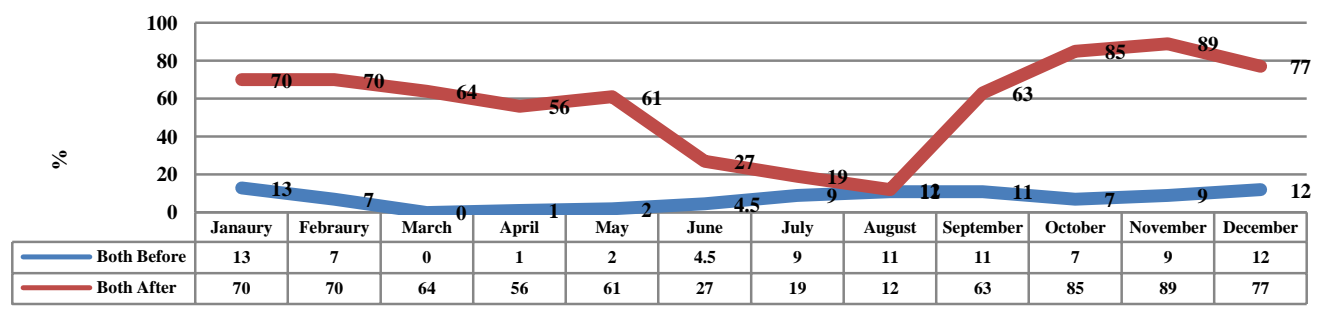

Figure 4. Vegetable grown both in Kaski and Kapilbastu districts

\section{Production of vegetables in different months of the year}

Figure 4 and 5 present the production of vegetables in kilograms throughout the year in kaski and Kapilbastu, respectively. The figure indicates that even ten years ago, the production of vegetables by the sample household was in every month in Kaski whereas the production of vegetables was only two months that is November and December in the case of Kapilbastu. There has been a significant improvement in the production of vegetables after ten years in both the studied area. The figure clearly shows that there was a continuous production and supply of vegetables from the farms and indicates that farmers are shifting towards commercialization. Comparing the situation of vegetable production before and after ten years, the production was found to be round the year and significant increase in volume except the month of August. The production of vegetable during the month of August was risky and challenging due to rainy season and water lodging condition in the field. 


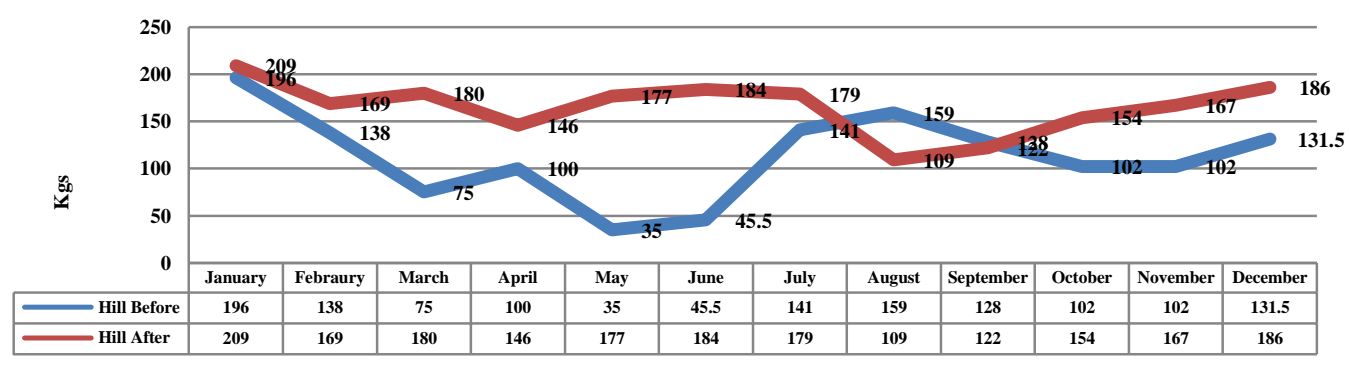

Figure 5 . Vegetables production ( Kg)in Kaski hills

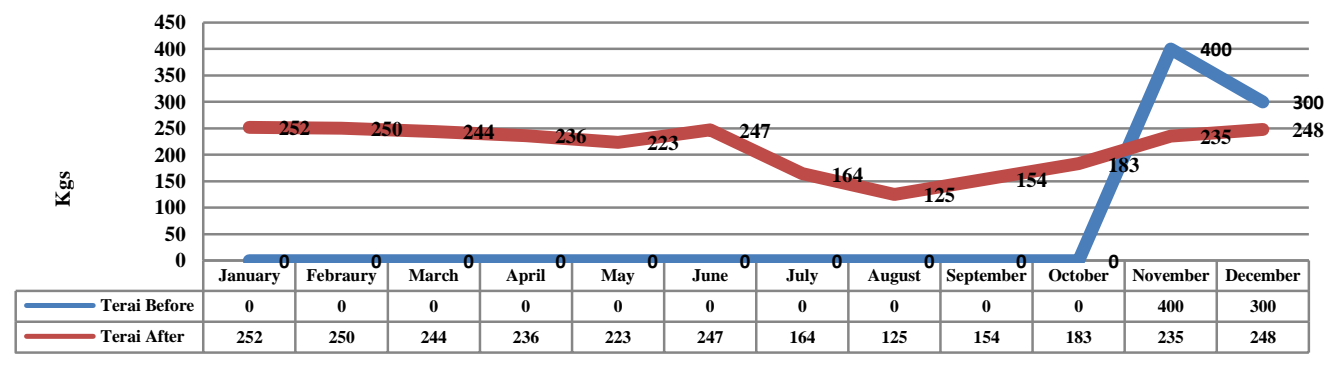

Figure 6. Vegetables production ( Kg) Kapilbastu- Terai

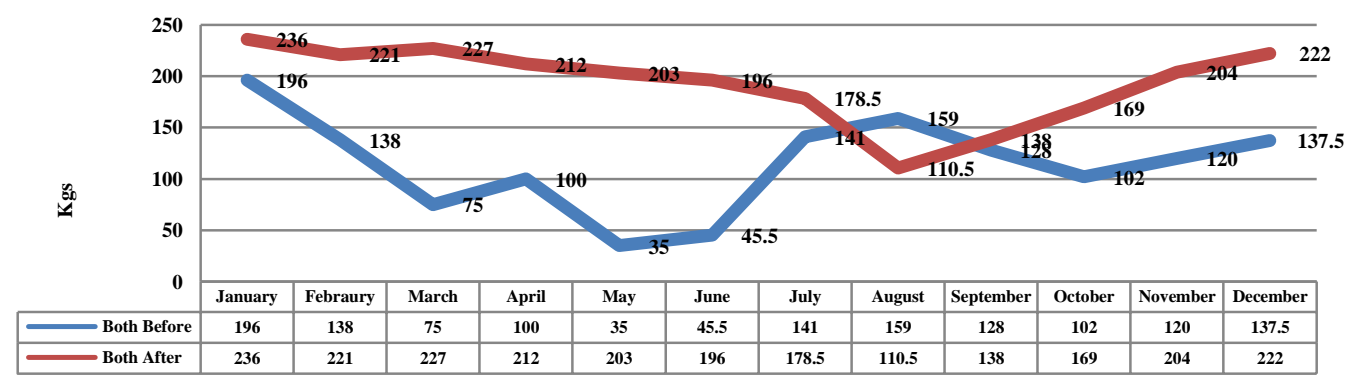

Figure 7. Vegetable production $(\mathrm{Kg})$ in Kaski and Kapilbastu districts

\section{Market players for the sale of vegetable}

Market players for selling vegetables in the study areas were farmers themselves, wholesaler, and farmers from the neighboring villages, collector and exporters. The findings reveal that most of the produce was sold by producers followed by wholesalers and neighboring farmers. Only less than $3 \%$ of the produce was sold to exporter which may be exported to India specially the rainy season tomato that was difficult to produce in Terai area due excessive heat and water lodged condition. To avoid all these condition plastic house control rainfall and water logged condition and organic tomato farming could control to some extent (Letourneau and Goldstein, 2001) . But the tomato cannot thrive well temperature above $35^{\circ} \mathrm{C}$ and certain varieties were only tolerant to this 
temperature (Lohar and Peat, 1998). This was the main reason that there were no vegetables grown and marketed ten years ago in the case of Kapilbastu (Adhikari and Basnyat, 1998) . Comparing the situation before and after ten years, it was observed that there hasdbeen increased sell directly to the market by producer followed by wholesaler and exporter. The sale of vegetable to neighboring villager and collector had been decreased significantly (Fig.7)

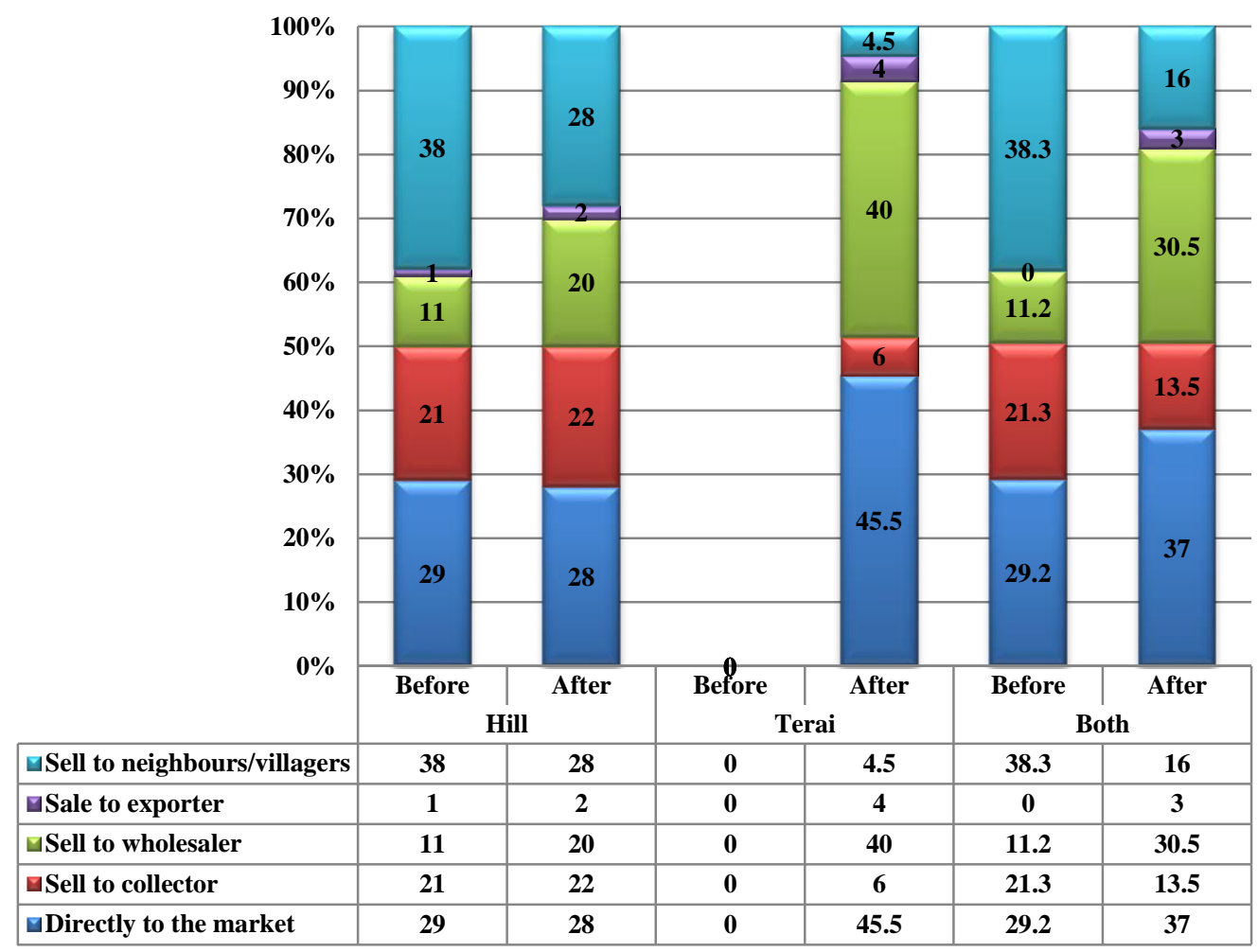

Figure 8. Sell of vegetable to different market actors

\section{Vegetable farming and poverty reduction}

We show that subjective poverty lines can be derived using simple qualitative assessments of perceived consumption adequacy based on a household survey. We implement the method using survey data for Jamaica and Nepal. Respondents were asked whether their consumptions of food, housing, and clothing were adequate for their family's needs. The implied poverty lines are robust to alternative methods of dealing with other components of expenditure. The aggregate poverty rates accord quite closely with those based on independent "objective" poverty lines. However, there are notable differences in the geographic and demographic poverty profiles (Pradhan and Ravallion, 2000), climate change and poverty (Gentle and Maraseni, 2012). Because of poverty people have started migration to foreign country or even internal migration to the cities looking for jobs (Kumar, 2004). One-fifth of the poverty reduction in Nepal occurring between 1995 and 
2004 can be attributed to higher levels of work-related migration and remittances sent home (Kumar, 2004). Cash crop cultivation escape poverty (Brown and Kennedy, 2005). The role of small farmers in poverty reduction (Lipton, 2006). Urban agriculture could play a major role in alleviate food insecurity and poverty (Zezza and Tasciotti, 2010).

\section{Conclusion}

The result of the study revealed that the number of farmers growing different kinds of vegetables is increasing, the production and supply of vegetables in the market is also regularly increasing. There have been improvements in the access of agri-inputs in vegetable cultivation, production technologies and marketing channels to market their produce. However, the area under vegetable cultivation is very small, there has been an increase under the area of vegetable cultivation and shift from subsistence farming to commercialize. Also it was observed that majority of the sample households were found increased their income through vegetable cultivation in the study area.

\section{Acknowledgements}

Thanks are due to the IDE- International, an NGO, Denver, USA that prepared the detailed PRISM Manual for PRISM application in different IDE program countries across the world. Appreciation goes to respondents of Kapilbastu and Kaski districts who provided information during the field survey. The author is highly grateful to Dr. Umed Kumar Pun for providing invaluable suggestions to make the study a success.

\section{References}

Abawi, GS., and Widmer, TL.2000. Impact of soil health management practices on soilborne pathogens, nematodes and root diseases of vegetable crops. Applied Soil Ecology 15, 37-47.

Adesina, AA, and Baidu-Forson, J. 1995. Farmers' perceptions and adoption of new agricultural technology: evidence from analysis in Burkina Faso and Guinea, West Africa. Agricultural Economics 13, 1-9.

Adhikari, TB, and Basnyat, RC.1998. Effect of crop rotation and cultivar resistance on bacterial wilt of tomato in Nepal. Canadian Journal of Plant Pathology 20, 283287.

Bazzano, L; Serdula, M, and Liu, S. 2003. Dietary intake of fruits and vegetables and risk of cardiovascular disease. Current Atherosclerosis Reports 5, 492-499.

Brown, S, and Kennedy, G. 2005. A case study of cash cropping in Nepal: Poverty alleviation or inequity? Agriculture and Human Values 22, 105-116.

Byerlee, D, (eds). 1994. "Technology transfer systems for improved crop management: lessons for the future. ," pp. 1- 208-230 
Dutt, B. 2014. Strategies for setting and running of small scale enterprises by women entrepreneurs of Kangra District of Himachal Pradesh. J. Agriculture Extension and Rural Development 6, 35-46.

Fafchamps, M. 1992. Cash Crop Production, Food Price Volatility, and Rural Market Integration in the Third World. American Journal of Agricultural Economics 74, 90-99.

Gentle, P and Maraseni, TN. 2012. Climate change, poverty and livelihoods: adaptation practices by rural mountain communities in Nepal. Environmental Science \& Policy 21, 24-34.

Ichiyanagi, K; Yamanaka, MD; Muraji, Y; and Vaidya, BK. 2007. Precipitation in Nepal between 1987 and 1996. International Journal of Climatology 27, 1753-1762.

Jetiyanon, K; Fowler, WD; and Kloepper, JW.(2003. Broad-Spectrum Protection Against Several Pathogens by PGPR Mixtures Under Field Conditions in Thailand. Plant Disease 87, 1390-1394

Kansakar, SR; Hannah, DM; Gerrard, J; and Rees, G. 2004. Spatial pattern in the precipitation regime of Nepal. International Journal of Climatology 24, 16451659.

Kant, A. 2003. Reported Consumption of Low-Nutrient-Density Foods by American Children and Adolescents: Nutritional and health Correlates, NHANES III, 1988 to 1994 Arch Pediatr Adolesc Med. 157, 789-796.

Knai, CC; Pomerleau, J; Lock, K; and McKee, M. 2006. Getting children to eat more fruit and vegetables: A systematic review. Preventive Medicine 42, 85-95.

Koundouri, P; Nauges, CI., and Tzouvelekas, V. 2006. Technology Adoption under Production Uncertainty: Theory and Application to Irrigation Technology. American Journal of Agricultural Economics 88, 657-670.

Krebs-Smith, SM., Reedy, J; and Bosire, C.2010. Healthfulness of the U.S. Food Supply: Little Improvement Despite Decades of Dietary Guidance. American Journal of Preventive Medicine 38, 472-477.

Kumar, B. 2004. Migration, Poverty and Development in Nepal. Asian and Pacific Migration Journal 13, 205-232.

Lampe, JW. 1999. Health effects of vegetables and fruit: assessing mechanisms of action in human experimental studies. The American Journal of Clinical Nutrition 70, 475s-490s.

Letourneau, DK and Goldstein, B. 2001. Pest damage and arthropod community structure in organic vs. conventional tomato production in California. Journal of Applied Ecology 38, 557-570.

Lipton, M. 2006. Can the small farmers survive, prosper or be the key channel to cut mass poverty? . Electronic J. of Agricultural and Development Economics 3, 58-85. 
Lohar, DP and Peat, WE. 1998. Floral characteristics of heat-tolerant and heat-sensitive tomato (Lycopersicon esculentum Mill.) cultivars at high temperature. Scientia Horticulturae 73, 53-60.

Loureno, A; Alves, A; Fugi, CGQ; and Matos, ES. 2008. Outbreaks of Trialeurodes vaporariorum (West.) (Hemiptera: Aleyrodidae) under field conditions in the State of SÃ£o Paulo, Brazil. Neotropical Entomology 37, 89-91.

Maxwell, S and Slater, R.2003. Food Policy Old and New. Development Policy Review 21, 531-553.

Moser, PB., Reynolds, RD., Acharya, S., Howard, MP., and Andon, M B. 1988. Calcium and magnesium dietary intakes and plasma and milk concentrations of Nepalese lactating women. The American Journal of Clinical Nutrition 47, 735-9.

Opara, LU. 2003. Traceability in agriculture and food supply chain: A review of basic concepts, technological implications, and future prospects. Food, Agriculture and Environment 1, 101-106.

Pokherel, DM. 2010. Comparison of Farm Production and Marketing Cost and Benefit Among Selected Vegetable Pockets in Nepal. J. Agriculture and Environment 11, $10-15$.

Pradhan, M and Ravallion, M. 2000. Measuring Poverty Using Qualitative Perceptions of Consumption Adequacy. Review of Economics and Statistics 82, 462-471.

Rana, AN. 1990. Vegetable production policy in Nepal In "Vegetables research and development in South Asia " (S. Shanmugasundaram, ed.), pp. 136-147. AVRDC Pakistan.

Rasmussen, M; Krolner, R; Klepp, KI., Lytle, L; Brug, J; Bere, E; and Due, P. 2006. Determinants of fruit and vegetable consumption among children and adolescents: a review of the literature. Part I: quantitative studies. International Journal of Behavioral Nutrition and Physical Activity 3, 22.

Sunding, D and Zilberman, D. 2001. Chapter 4 The agricultural innovation process: Research and technology adoption in a changing agricultural sector. In "Handbook of Agricultural Economics", Vol. Volume 1, Part A, pp. 207-261. Elsevier.

Susanne, P and Carolyn, F. 2005. Exploring the gap between attitudes and behaviour: Understanding why consumers buy or do not buy organic food. British Food Journal 107, 606-625.

Tamrakar, NK; Yokota, S; and Osaka, O. 2002. A toppled structure with sliding in the Siwalik Hills, midwestern Nepal. Engineering Geology 64, 339-350.

Tilman, D; Cassman, KG., Matson, PA; Naylor, R; and Polasky, S. 2002. Agricultural sustainability and intensive production practices. Nature 418, 671-677.

Welch, RM and Graham, RD. 1999. A new paradigm for world agriculture: meeting human needs: Productive, sustainable, nutritious. Field Crops Research 60, 1-10. 
Zeller, M; Diagne, A; and Mataya, C. 1998. Market access by smallholder farmers in Malawi: implications for technology adoption, agricultural productivity and crop income. Agricultural Economics 19, 219-229.

Zezza, A and Tasciotti, L. 2010. Urban agriculture, poverty, and food security: Empirical evidence from a sample of developing countries. Food Policy 35, 265-273.

Zwick, D; Bonsu, SK; and Darmody, A. 2008. Putting Consumers to Work: 'Co-creation` and new marketing govern-mentality. Journal of Consumer Culture 8, 163-196. 